Onopriienko Stanislav,

Candidate of Technical Sciences, Senior

Lecturer, Taras Shevchenko National

University of Kyiv, Kyiv, Ukraine

ORCID ID 0000-0002-5524-1798

\title{
COUNTERING THREATS TO NATIONAL SECURITY IN THE INFORMATION SPHERE: THE LEGAL ASPECT
}

The article contains an analysis of trends in countering threats to national security. The author substantiates that the peculiarity of modern society is the development of information technologies that allow much faster production operations that previously took a lot of time and effort. Such trends can save human, temporary and other material resources. At the same time, informatization contributed to the emergence of the phenomenon of an excessive dependence of a person on information technology, with the help of which he is now able to fulfill his functional duties. A person becomes alienated from the means of production, the employee turns into a passive application to certain programs, entering certain information and data into them, receiving and printing the results of their analysis, and not understanding even the fundamental principles of information processing.

The author substantiates that under such conditions the victimization of the most vulnerable part of any information security system - the human being - increases.

The article contains an analysis of the provisions of the Law of Ukraine "On National Security of Ukraine". The author claims that the said law is more perfect than the previous legislative act, but at the same time a large number of gaps remained in it related to determining the features of ensuring information security. Overcoming these shortcomings and gaps is a condition and a necessary factor for creating a reliable mechanism for ensuring information security in Ukraine.

The author concludes that the problem of countering information threats in the field of national security is today the most important for ensuring state sovereignty, 
territorial integrity and independence of our state. The efforts of state authorities and local self-government, scientists, all active subjects of civil society should be aimed at solving this problem. The legislation regulating issues related to ensuring national security in the information sphere is notable for its inconsistency, the presence of a large number of gaps, and it does not allow determining the legal status, scope of rights, duties and responsibilities of entities whose activities should ensure national security in the information sphere.

Key words: information security, national security, security and defense sector, information legislation, legal mechanism, information technology.

\section{REFERENCES}

1. Kirian V.O. (2012) Informatsiolohichnyi zmist ideolohii bezpeky. "Information content of security ideology". Pravova informatyka. No. 33 (1). P. 39-43. [in Ukrainian].

2. Shopina I.M., Koropatnik I.M. (2017) Rol informatsiinoi kultury v pidvyshchenni efektyvnosti funktsionuvannia Zbroinykh Cyl Ukrainy. "The role of information culture in improving the functioning of the Armed Forces of Ukraine". Nauka i pravookhorona. No. 2. P. 47-54. [in Ukrainian].

3. Pro natsionalnu bezpeku: Zakon Ukrainy vid 21 chervnia 2018 roku № 2469VIII. "On National Security": Law of Ukraine of June 21, 2018 No. 2469-VIII. Vidomosti Verkhovnoi Rady Ukrainy. 2018. No. 31. Art.241. [in Ukrainian]

4. Pro osnovni zasady zabezpechennia kiberbezpeky Ukrainy: Zakon Ukrainy vid 5 zhovtnia 2017 roku № 2163-VIII. “On the Fundamental Principles of Cybersecurity of Ukraine": Law of Ukraine of October 5, 2017 No. 2163-VIII. Vidomosti Verkhovnoi Rady Ukrainy. 2017. No.45. Art.403. [in Ukrainian] 